\title{
The Glass-Coated Melt Spinning of Superconductors
}

\author{
By Tomoko Gotō*
}

\begin{abstract}
The glass-coated melt spinning of superconductor was investigated to produce a fine superconducting filament.

The melt spinning of $\mathrm{V}_{3} \mathrm{Si}$ was examined using the vycor glass and a $\mathrm{V}_{3} \mathrm{Si}$ filament thicker than $50 \times 10^{-6} \mathrm{~m}$ in diameter and of a few meters in length was obtained. This filament was a brittle material with tensile strength of $20 \mathrm{MPa}$ and elongation of $0.2 \%$ and had a high superconducting transition temperature, $T_{c}=17 \mathrm{~K}$.

The continuous melt spinning of eutectic mixtures of copper alloys and superconductors with melting points up to $1580 \mathrm{~K}$ was made using the pyrex glass from melts at $1630 \mathrm{~K}$ with winding speeds ranging from $7.95 \mathrm{~m} \cdot \mathrm{s}^{-1}$ to $1.50 \mathrm{~m} \cdot \mathrm{s}^{-1}$. The filament of $10 \times 10^{-6} \mathrm{~m}$ in diameter had a high tensile strength of $10^{3} \mathrm{MPa}$. A dilute copper alloy filament containing small amounts of $\mathrm{Nb}-\mathrm{Sn}$ and $\mathrm{Nb}-\mathrm{Ge}$ was also successfully produced. The maximum $T_{c}, 8 \mathrm{~K}$, was observed for the $\mathrm{Cu}_{93.2} \mathrm{Nb}_{4.5} \mathrm{Sn}_{2.3}$ filament annealed at $873 \mathrm{~K}$ for $7.2 \times 10^{5} \mathrm{~s}$.
\end{abstract}

(Received March 16, 1981)

\section{Introduction}

It is well known that superconductors with relatively high superconducting transition temperatures $\left(T_{c}>10 \mathrm{~K}\right)$ are usually brittle and difficult to be fabricated into tapes or wires which are useful in large scale engineering applications such as superconducting magnets, power transmission lines, etc.

Recently, much effort has been devoted to developing multifilamentary superconducting composites by the "bronze technique" and several other approaches ${ }^{(1)}$. On the other hand, Tsuei obtained high critical temperature superconducting tapes via the amorphous state ${ }^{(2)}$.

Grodkiewicz produced a superconducting $\mathrm{V}_{3} \mathrm{Si}$ filament by drawing in a fused silica tube $^{(3)}$. We developed a fabrication technique of the glass-coated melt spinning of metals and alloys, whereby continuous filaments finer than $10 \times 10^{-6} \mathrm{~m}$ in diameter of copper, stainlesssteel or other alloys were produced directly from the melts of these materials ${ }^{(4)}$.

In the present work, this technique was used to produce continuous superconducting filaments.

* Department of Polymer Technology, Nagoya Institute of Technology, Gokiso-chō, Shōwa-ku, Nagoya 466, Japan.

\section{Experimental}

By using pure niobium, vanadium, silicon, gallium, germanium, tin, aluminum and copper as starting materials, various kinds of mother alloys were prepared by melting them in a vacuum.

The melt spinning of these alloys was studied by using a casting apparatus as described before $^{(4)}$. About $1 \mathrm{~g}$ of each alloy was placed in a glass tube and melted by induction heating. When the glass-tube containing the molten alloy was drawn, the alloy was stretched to form a glass-coated metallic filament and coiled on a winding drum. The coating glass was removed in a $45 \%$ HF aqueous solution.

The tensile strength of the filaments produced by this method was measured with an Instron type machine. The critical temperature, $T_{c}$ was measured by the resistive method. In these measurements it was necessary to construct special devices because of small sizes of the filaments.

\section{Results}

In the glass-coated melt spinning it is very important that the wettability between the molten metal and coated glass is good and that the melting point of the metal is close to the flow point of the glass used. The wettability 
of $\mathrm{Nb}-\mathrm{Ge}, \mathrm{Nb}-\mathrm{Ga}, \mathrm{Nb}-\mathrm{Al}, \mathrm{Nb}-\mathrm{Sn}$ and $\mathrm{V}-\mathrm{Ga}$ system alloys is so poor that the spinning could not be performed.

In the case of $\mathrm{V}_{3} \mathrm{Si}$, vycor glass with a flow point of $2270 \mathrm{~K}$ was used. The spinning of $\mathrm{V}_{3} \mathrm{Si}$ is difficult due to the high flow point and the rapid quenching of the glass, and a brittle nature of the alloy. Although the $\mathrm{V}_{3} \mathrm{Si}$ filament of a few meters in length was obtained, it was not coiled on a winding drum. The filament obtained was thicker than $50 \times 10^{-6} \mathrm{~m}$ in diameter and had a low tensile strength of $20 \mathrm{MPa}$ and an elongation of $0.2 \%$.

The melt spinning of eutectic mixtures of copper alloys and superconductors with melting points up to $1580 \mathrm{~K}$ were then examined by using of pyrex glass (flow point: $1370 \mathrm{~K})$. The continuous $\mathrm{Cu}_{70} \mathrm{Si}_{30}+\mathrm{V}_{3} \mathrm{Si}(10$ mass $\%), \mathrm{Cu}_{65} \mathrm{Ge}_{35}+\mathrm{Nb}_{3} \mathrm{Ge}(10$ mass $\%)$ and $\mathrm{Cu}_{84} \mathrm{Sn}_{16}+\mathrm{Nb}_{3} \mathrm{Sn}(10$ mass $\%)$ filaments were produced from the molten state at $1630 \mathrm{~K}$ with various winding speeds ranging from $7.95 \mathrm{~m}$. $\mathrm{s}^{-1}$ to $1.50 \mathrm{~m} \cdot \mathrm{s}^{-1}$. The spinning of $\mathrm{Cu}_{70} \mathrm{Ga}_{30}+$ $\mathrm{V}_{3} \mathrm{Ga}(10$ mass $\%$ ) alloy was not possible because of poor wettability to the coated glass. The filament obtained had a lustrous smooth surface and were free from pinholes. Variations in average diameter and tensile strength of the filaments with changing winding speed were measured and the results are shown in Table 1. The diameter decreases with increasing winding speed. $\mathrm{Cu}-\mathrm{Si}$ and $\mathrm{Cu}-\mathrm{Ge}$ alloy filaments have a high tensile strength of the order of $10^{3} \mathrm{MPa}$. Stress-strain curves of these filaments showed that the specimens were apparently stretched straightly to the breaking point as observed on the $\mathrm{Ag}_{60} \mathrm{Cu}_{40}$ eutectic filaments ${ }^{(5)}$.
Cross-sections of the filaments after chemical etching in the mixture of $\mathrm{NH}_{4} \mathrm{OH} 5 \times 10^{-5} \mathrm{~m}^{3}$ and $\mathrm{H}_{2} \mathrm{O}_{2} 2 \times 10^{-5} \mathrm{~m}^{3}$ were observed by scanning electron microscopy. Photograph 1 shows the cross-section of $\mathrm{Cu}_{65} \mathrm{Ge}_{35}+\mathrm{Nb}_{3} \mathrm{Ge}$ filament. The filament consists of fine crystal grains with a grain size of $1000 \times 10^{-10} \mathrm{~m}$.

It is known that copper containing small amounts of superconducting particles exhibits superconductivity. Tsuei et al. and Gupta et al. reported on the superconducting characteristics in dilute $\mathrm{Cu}-\mathrm{Nb}$ alloys prepared by rapid quenching and subsequent annealing at 1073 $\mathrm{K}^{(6)(7)}$. Nagata et al. also reported superconducting properties and microstructures of dilute copper alloys containing small amounts of $\mathrm{V}_{3} \mathrm{Ga}$ particles ${ }^{(8)}$. The present method gives filaments with a cooling rate of about $10^{5}$ $\mathrm{K} \cdot \mathrm{s}^{-1}$ through the drawing process. Thus, the melt spinning of dilute copper alloys containing

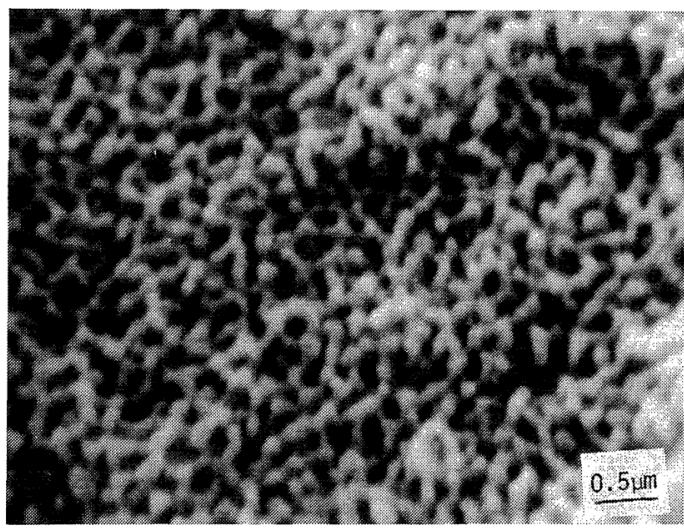

Photo. 1 Scanning electron micrograph of the crosssection of the $\mathrm{Cu}_{65} \mathrm{Ge}_{35}+10$ mass $\% \mathrm{Nb}_{3} \mathrm{Ge}$ filament after chemical etching.

Table 1 Spinning conditions and average strength of eutectic mixture filaments of copper alloys and superconductors produced by the melt spinning with pyrex glass.

\begin{tabular}{|c|c|c|c|c|}
\hline Filament & $\begin{array}{l}\text { Winding } \\
\text { speed } \\
\left(\mathrm{m} \cdot \mathrm{s}^{-1}\right)\end{array}$ & $\begin{array}{c}\text { Diameter } \\
\left(\times 10^{-6} \mathrm{~m}\right)\end{array}$ & $\begin{array}{c}\text { Tensile } \\
\text { strength } \\
\text { (MPa) }\end{array}$ & $\underset{(\%)}{\text { Elongation }}$ \\
\hline \multirow[t]{2}{*}{$\mathrm{Cu}_{70} \mathrm{Si}_{30}+10$ mass $\% \mathrm{~V}_{3} \mathrm{Si}$} & 2.63 & 6 & 910 & 2.2 \\
\hline & 1.50 & 12 & 1070 & 2.4 \\
\hline \multirow[t]{3}{*}{$\mathrm{Cu}_{65} \mathrm{Ge}_{35}+10$ mass $\% \mathrm{Nb}_{3} \mathrm{Ge}$} & 3.95 & 9 & 1230 & 2.5 \\
\hline & 2.63 & 11 & 1150 & 2.0 \\
\hline & 1.50 & 11 & 1070 & 1.7 \\
\hline \multirow[t]{2}{*}{$\mathrm{Cu}_{86} \mathrm{Sn}_{14}+10$ mass $\% \mathrm{Nb}_{3} \mathrm{Sn}$} & 7.95 & 6 & 400 & 1.4 \\
\hline & 1.50 & 14 & 650 & 1.9 \\
\hline
\end{tabular}


small amounts of superconductor with melting points up to $1580 \mathrm{~K}$ were examined.

The continuous melt spinning of the $\mathrm{Cu}_{99.5} \mathrm{Nb}_{0.3} \mathrm{Sn}_{0.2}, \quad \mathrm{Cu}_{97.7} \mathrm{Nb}_{1.5} \mathrm{Sn}_{0.8}, \mathrm{Cu}_{95.5}$ $\mathrm{Nb}_{3} \mathrm{Sn}_{1.5}, \mathrm{Cu}_{93.2} \mathrm{Nb}_{4.5} \mathrm{Sn}_{2.3}$ and $\mathrm{Cu}_{95.5} \mathrm{Nb}_{3}$ $\mathrm{Ge}_{1.5}$ alloys was made from the melts of these alloys at $1630 \mathrm{~K}$ with winding speeds ranging from $0.95 \mathrm{~m} \cdot \mathrm{s}^{-1}$ to $2.63 \mathrm{~m} \cdot \mathrm{s}^{-1}$. Average diameters and tensile strengths of the filaments spun at verious winding speeds are shown in Table 2. A maximum tensile strength of 370 $\mathrm{MPa}$ is obtained for the $\mathrm{Cu}_{95.5} \mathrm{Nb}_{3} \mathrm{Sn}_{1.5}$ filament. These filaments have a wide range of plasticity as pure copper filament ${ }^{(5)}$. Fractographs of the $\mathrm{Cu}_{95.5} \mathrm{Nb}_{3} \mathrm{Sn}_{1.5}$ filament are shown in Photo. 2. Many slip lines and local shrinking (necking) are observed.

$T_{c}$ of the filaments obtained was determined by measuring changes in resistivity using a chromel-gold $+0.007 \%$ iron thermocouple. A typical result of the resistivity measurement on the $\mathrm{V}_{3} \mathrm{Si}$ filament is shown in Fig. 1. A wide temperature range of normal-superconducting transition, probably due to scattered distribution of $\mathrm{V}_{3} \mathrm{Si}$ precipitate sizes and interparticle distances, is observed. $T_{c}$ and $\Delta T_{c}$ were defined as shown in Fig. 1, and determined to be $17 \mathrm{~K}$ and $3.0 \mathrm{~K}$, respectively, for the $\mathrm{V}_{3} \mathrm{Si}$ filament. It should be also mentioned that vanadium and silicon may react readily to form $\mathrm{V}_{3} \mathrm{Si}$ compound; e.g.; Tachikawa and Yoshida obtained $\mathrm{V}_{3} \mathrm{Si}$ of $T_{c}=17.0 \mathrm{~K}$ by reacting a vanadium tape
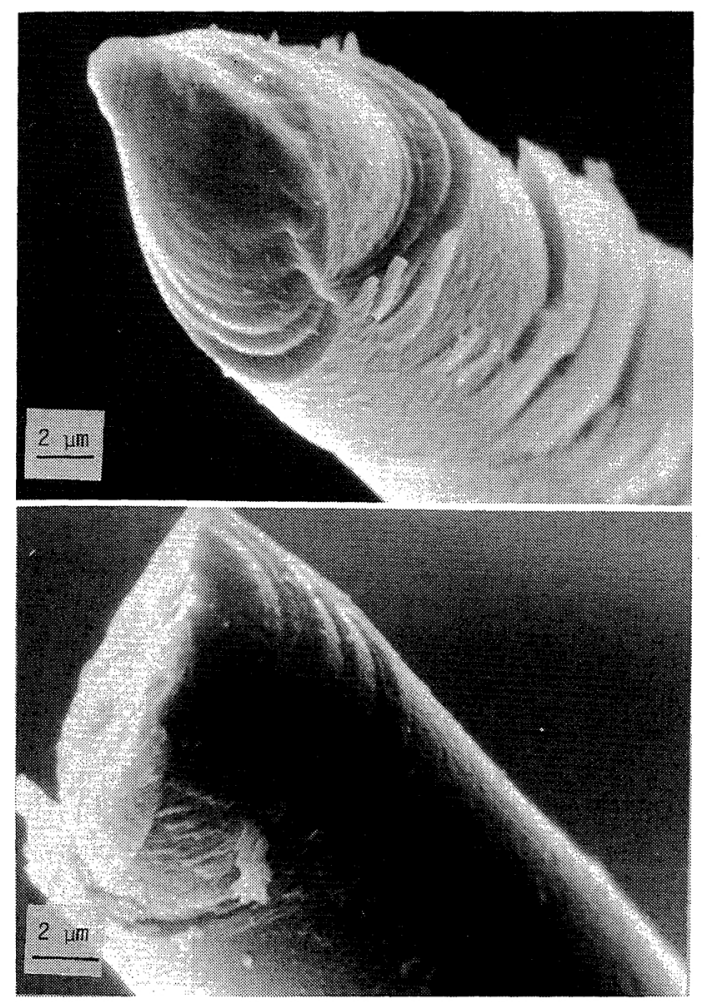

Photo. 2 Fracture morphology of opposing segments of the $\mathrm{Cu}_{95.5} \mathrm{Nb}_{3} \mathrm{Sn}_{1.5}$ filament fractured at 270 $\mathrm{MPa}$ and $4.0 \%$ elongation.

and overlying silicone grease ${ }^{(9)}$.

In a material exhibiting superconductivity due to the proximity effect, it is known that $T_{c}$ varies drastically with the sample current

Table 2 Spinning conditions and average strength of dilute copper alloy filaments containing small amounts of $\mathrm{Nb}-\mathrm{Sn}$ or $\mathrm{Nb}-\mathrm{Ge}$ produced by the melt spinning with pyrex glass.

\begin{tabular}{|c|c|c|c|c|}
\hline Filament & $\begin{array}{l}\text { Winding } \\
\text { speed } \\
\left(\mathrm{m} \cdot \mathrm{s}^{-1}\right)\end{array}$ & $\begin{array}{c}\text { Diameter } \\
\left(\times 10^{-6} \mathrm{~m}\right)\end{array}$ & $\begin{array}{l}\text { Tensile } \\
\text { strength } \\
(\mathrm{MPa})\end{array}$ & $\begin{array}{l}\text { Elongation } \\
(\%)\end{array}$ \\
\hline \multirow[t]{3}{*}{$\mathrm{Cu}_{99.5} \mathrm{Nb}_{0.3} \mathrm{Sn}_{0.2}$} & 1.50 & 8 & 140 & 3.8 \\
\hline & 2.63 & 9 & 180 & 5.0 \\
\hline & 3.95 & 5 & 210 & 4.1 \\
\hline \multirow[t]{2}{*}{$\mathrm{Cu}_{97.7} \mathrm{Nb}_{1.5} \mathrm{Sn}_{0.8}$} & 1.50 & 14 & 180 & 4.0 \\
\hline & 2.63 & 9 & 220 & 2.7 \\
\hline \multirow[t]{3}{*}{$\mathrm{Cu}_{95.5} \mathrm{Nb}_{3} \mathrm{Sn}_{1.5}$} & 0.95 & 16 & 270 & 2.3 \\
\hline & 1.50 & 10 & 370 & 3.9 \\
\hline & 2.63 & 10 & 200 & 6.0 \\
\hline \multirow[t]{2}{*}{$\mathrm{Cu}_{93.2} \mathrm{Nb}_{4.5} \mathrm{Sn}_{2.3}$} & 1.50 & 10 & 310 & 3.9 \\
\hline & 2.63 & 12 & 230 & 5.6 \\
\hline \multirow[t]{3}{*}{$\mathrm{Cu}_{95.5} \mathrm{Nb}_{3} \mathrm{Ge}_{1.5}$} & 0.95 & 11 & 180 & 3.9 \\
\hline & 1.50 & 9 & 150 & 12.0 \\
\hline & 2.63 & 10 & 210 & 11.0 \\
\hline
\end{tabular}




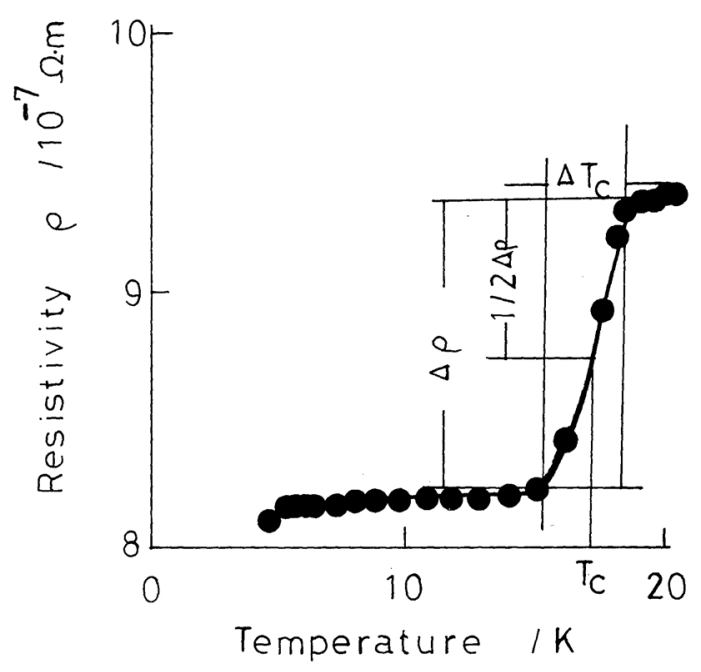

Fig. 1 Electrical resistivity of $\mathrm{V}_{3} \mathrm{Si}$ filament as a function of temperature.

density $^{(10)(11)}$. The filament produced in the present study is so fine that the sample current density $\left(J_{s}\right)$ is very high ranging from $10^{6}$ $\mathrm{A} \cdot \mathrm{m}^{-2}$ to $10^{8} \mathrm{~A} \cdot \mathrm{m}^{-2} . T_{c}, \Delta T_{c}$ and $J_{s}$ for the eutectic mixture filaments and dilute copper alloy filaments are listed in Table 3 and 4, respectively. Since $J_{s}$ was near the critical current density, $T_{c}$ was relatively low compared with those of the copper alloys produced by other methods ${ }^{(8)(10)-(12)}$. The superconductivity is observed for the as-drawn $\mathrm{Cu}_{65} \mathrm{Ge}_{35}+\mathrm{Nb}_{3} \mathrm{Ge}$ and $\mathrm{Cu}_{95.5} \mathrm{Nb}_{3} \mathrm{Ge}_{1.5}$ filaments. $T_{c}$ of the dilute $\mathrm{Cu}-\mathrm{Nb}-\mathrm{Sn}$ filament increases with increasing $\mathrm{Nb}$ or $\mathrm{Sn}$ content. The maximum $T_{c}, 8 \mathrm{~K}$, was observed for the $\mathrm{Cu}_{93.2} \mathrm{Nb}_{4.5} \mathrm{Sn}_{2.3}$ filament annealed at $873 \mathrm{~K}$ for $7.2 \times 10^{5} \mathrm{~s}(200 \mathrm{~h})$.

\section{Conclusion}

The glass-coated melt spinning of superconductor to prepare a fine superconducting filament was investigated. The melt spinning of $\mathrm{V}_{3} \mathrm{Si}$ was examined using the vycor glass, and a $\mathrm{V}_{3}$ Si filament thicker than $50 \times 10^{-6} \mathrm{~m}$ in diameter and of a few meters in length was obtained. This filament was a brittle material with a tensile strength of $20 \mathrm{MPa}$ and elongation of $0.2 \%$ and had a high superconducting transition temperature of $T_{c}=17 \mathrm{~K}$.

The continuous melt spinning of eutectic

Table $3 T_{c}, \Delta T_{c}$ and $J_{s}$ of the $\mathrm{V}_{3} \mathrm{Si}$ and eutectic copper alloy filaments.

\begin{tabular}{llccc}
\hline \multicolumn{1}{c}{ Filament } & Heat treatment & $T_{c}(\mathrm{~K})$ & $\Delta T_{c}(\mathrm{~K})$ & $J_{s}\left(\times 10^{7} \mathrm{~A} \cdot \mathrm{m}^{-2}\right)$ \\
\hline $\mathrm{V}_{3} \mathrm{Si}$ & as drawn & 17 & 3.0 & 0.17 \\
$\mathrm{~V}_{3} \mathrm{Si}$ & $873 \mathrm{~K}, 3.6 \times 10^{5} \mathrm{~s}$ & 12 & 0.4 & 0.26 \\
$\mathrm{Cu}_{70} \mathrm{Si}_{30}+10$ mass $\% \mathrm{~V}_{3} \mathrm{Si}$ & $873 \mathrm{~K}, 3.6 \times 10^{5} \mathrm{~s}$ & 4.6 & 1 & 2.0 \\
$\mathrm{Cu}_{86} \mathrm{Sn}_{14}+10$ mass $\% \mathrm{Nb}_{3} \mathrm{Sn}$ & $873 \mathrm{~K}, 3.6 \times 10^{5} \mathrm{~s}$ & - & - & 6.0 \\
$\mathrm{Cu}_{65} \mathrm{Ge}_{35}+10$ mass $\% \mathrm{Nb}_{3} \mathrm{Ge}$ & as drawn & 7 & 3.6 & 12 \\
$\mathrm{Cu}_{65} \mathrm{Ge}_{35}+10$ mass $\% \mathrm{Nb}_{3} \mathrm{Ge}$ & $623 \mathrm{~K}, 3.6 \times 10^{3} \mathrm{~s}$ & 6 & 1.4 & 2.9 \\
$\mathrm{Cu}_{65} \mathrm{Ge}_{35}+10$ mass $\% \mathrm{Nb}_{3} \mathrm{Ge}$ & $753 \mathrm{~K}, 3.6 \times 10^{3} \mathrm{~s}$ & 4.6 & 0.2 & 3.3 \\
\hline
\end{tabular}

Table $4 T_{c}, \Delta T_{c}$ and $J_{s}$ of the dilute copper alloy filaments.

\begin{tabular}{lllll}
\hline \multicolumn{1}{c}{ Filament } & Heat treatment & $T_{c}(\mathrm{~K})$ & $\Delta T_{c}(\mathrm{~K})$ & $J_{s}\left(\times 10^{7} \mathrm{~A} \cdot \mathrm{m}^{-2}\right)$ \\
\hline $\mathrm{Cu}_{99.5} \mathrm{Nb}_{0.3} \mathrm{Sn}_{0.2}$ & $873 \mathrm{~K}, 3.6 \times 10^{5} \mathrm{~s}$ & - & - & 0.45 \\
$\mathrm{Cu}_{97.7} \mathrm{Nb}_{1.5} \mathrm{Sn}_{\mathbf{0 . 7}}$ & $873 \mathrm{~K}, 7.2 \times 10^{5} \mathrm{~s}$ & 5.7 & 2.0 & 0.59 \\
$\mathrm{Cu}_{95.5} \mathrm{Nb}_{3} \mathrm{Sn}_{1.5}$ & $873 \mathrm{~K}, 3.6 \times 10^{5} \mathrm{~s}$ & 6.1 & 2.5 & 1.1 \\
& $873 \mathrm{~K}, 7.2 \times 10^{5} \mathrm{~s}$ & 5.7 & 1.5 & 2.4 \\
& $873 \mathrm{~K}, 10.8 \times 10^{5} \mathrm{~s}$ & 4.9 & 0.7 & 0.4 \\
$\mathrm{Cu}_{93.2} \mathrm{Nb}_{4.5} \mathrm{Sn}_{2.3}$ & as drawn & - & - & 2.0 \\
& $873 \mathrm{~K}, 3.6 \times 10^{5} \mathrm{~s}$ & 5.4 & 1.0 & 1.9 \\
& $873 \mathrm{~K}, 7.2 \times 10^{5} \mathrm{~s}$ & 8.0 & 4.5 & 1.9 \\
$\mathrm{Cu}_{95.5} \mathrm{Nb}_{3} \mathrm{Ge}_{1.5}$ & $873 \mathrm{~K}, 10.8 \times 10^{5} \mathrm{~s}$ & 5.2 & 0.7 & 1.4 \\
& as drawn & 6.1 & 2.0 & 1.9 \\
\hline
\end{tabular}


mixtures of copper alloys and superconductors with melting points up to $1580 \mathrm{~K}$ was made using the pyrex glass from melts at $1630 \mathrm{~K}$ with winding speeds ranging from $7.95 \mathrm{~m} \cdot \mathrm{s}^{-1}$ to $1.50 \mathrm{~m} \cdot \mathrm{s} .^{-1}$ The filament of $10 \times 10^{-6} \mathrm{~m}$ in diameter had a high tensile strength of $10^{3}$ $\mathrm{MPa}$. A dilute copper alloy filament containing small amounts of $\mathrm{Nb}-\mathrm{Sn}$ and $\mathrm{Nb}-\mathrm{Ge}$ was also successfully produced. The maximum $T_{c}, 8 \mathrm{~K}$, was observed for the $\mathrm{Cu}_{93.2} \mathrm{Nb}_{4.5} \mathrm{Sn}_{2.3}$ filament annealed at $873 \mathrm{~K}$ for $7.2 \times 10^{5} \mathrm{~s}$.

\section{Acknowledgements}

The author wishes to appreciate Mr. Imura's assistance in the low temperature electrical resistivity measurements. This work was supported partly by a Grant-Aid for Scientific Research from the Ministry of Education, Science and Culture (No. 56055022).

\section{REFERENCES}

(1) C. C. Tsuei, M. Suenaga and W. B. Sampson: Appl. Phys. Lett., 25 (1978), 318.

(2) C. C. Tsuei: Appl. Phys. Lett., 33 (1978), 262.

(3) W. H. Grodkiewicz: Mat. Res. Bull., 10 (1975), 1085.

(4) T. Gotō and M. Nagano: Trans. JIM, 18 (1977), 209, 562, 759; 19 (1978), 60.

(5) T. Gotō: Trans. JIM, 20 (1979) 377.

(6) C. C. Tsuei and L. N. Newkirk: J. Mate. Sci., 8 (1973), 1307.

(7) A. D. Gupta, B. L. Mordike and L. Schultze: Mate. Sci. Eng., 18 (1975), 137.

(8) A. Nagata, H. Hirayama, K. Noto and O. Izumi: J. Appl. Phys., 48 (1977), 5175.

(9) K. Tachikawa and Y. Yoshida: Jpn. J. Appl. Phys., 12 (1973), 1107.

(10) A. Nagata, O. Izumi and K. Noto: J. Mate. Sci., 13 (1978), 731.

(11) J. Bevk and J. P. Harbison: J. Mate. Sci., 14 (1979), 1457.

(12) Y. Yoshida and K. Tachikawa: J. Japan Inst. Metals., 37 (1973), 558 (in Japanese). 